Etnográfica

Revista do Centro em Rede de Investigação em

Antropologia

vol. 24 (3) | 2020

Vol. 24 (3)

\title{
Com e sem vizinhos: formas de habitar becos e pátios nos centros de Salvador e Lisboa
}

With and without neighbors: ways of inhabiting alleys and courtyards in the centers of Salvador and Lisbon

\section{Urpi Montoya Uriarte}

\section{(2) OpenEdition}

Journals

Edição electrónica

URL: https://journals.openedition.org/etnografica/8004

DOI: 10.4000/etnografica.8004

ISSN: 2182-2891

Editora

Centro em Rede de Investigação em Antropologia

Edição impressa

Data de publição: 1 outubro 2020

Paginação: 603-628

ISSN: 0873-6561

Refêrencia eletrónica

Urpi Montoya Uriarte, «Com e sem vizinhos: formas de habitar becos e pátios nos centros de Salvador e Lisboa», Etnográfica [Online], vol. 24 (3) | 2020, posto online no dia 31 outubro 2020, consultado o 20 janeiro 2022. URL: http://journals.openedition.org/etnografica/8004 ; DOI: https://doi.org/10.4000/ etnografica.8004

\section{(c) (i) (9)}

Etnográfica is licensed under a Creative Commons Attribution-NonCommercial 4.0 International License. 


\section{Com e sem vizinhos: formas de habitar becos e pátios nos centros de Salvador e Lisboa}

\section{Urpi Montoya Uriarte}

Este artigo tem como objetivo refletir sobre as relações entre espaço construído e práticas de habitar a partir do material etnográfico produzido em duas microlocalidades: o beco Camponesa e o pátio do Broas, situados no centro de Salvador e de Lisboa, respectivamente. Embora estes espaços partilhem uma história semelhante, sejam local de residência de setores populares e exibam formas físicas muito parecidas, eles apresentam formas de habitar bastante diferentes. Os dados empíricos produzidos no beco e no pátio analisados nos permitem afirmar que nem os lugares geram formas de habitar, nem o espaço construído engendra um conteúdo específico. As práticas do habitar com vizinhos derivam de outros fatores, dentre os quais destacamos o tempo livre decorrente do regime de trabalho no qual estão inseridos seus habitantes, a propriedade dos imóveis e a concepção de casa.

PALAVRAS-CHAVE: habitar, becos, pátios, centro, Salvador, Lisboa.

With and without neighbors: ways of inhabiting alleys and courtyards in the centers of Salvador and Lisbon - This article aims to reflect on the relationship between constructed space and living practices, based on the ethnographic material produced in two micro-locations: the Camponesa alley and the pátio do Broas, located in downtown Salvador and Lisbon, respectively. Although these spaces share a similar history, are places of residence of popular segments and exhibit very similar physical forms, they present different ways of living. The empirical data produced in the alley and courtyard analyzed allow us to affirm that neither the places generate ways of inhabiting nor the constructed space engenders a specific content. The practices of living with neighbors derive from other factors, among which we highlight the free time resulting from the work regime of its inhabitants, the property ownership and the conception of house.

KEYWORDS: dwelling, alleys, courtyard, center, Salvador, Lisbon.

MONTOYA URIARTE, Urpi (urpi@terra.com.br) - Departamento de Antropologia, Programa de Pós-Graduação em Antropologia, Universidade Federal da Bahia, Brasil. 


\section{ESTE ARTIGO TRATA DE BECOS E PÁTIOS, LUGARES EVITADOS OU SEQUER} percebidos pelos transeuntes desatentos que passam por suas entradas. Sua invisibilidade ou periculosidade os tornam lugares sobre os quais a maioria dos citadinos pouco sabe ou quer saber. Foi precisamente esta marginalidade ou marginalização de becos e pátios que nos fez adentrar neles pela primeira vez, surgindo desde então uma série de questionamentos: o que pensam seus moradores sobre este tipo de moradia? Que espécie de ambiente relacional se desenvolve nestes espaços? Será que a estreiteza física, tão evidente, é um fator determinante do ambiente relacional que neles é produzido? É possível falarmos de uma forma de habitar própria deste tipo de espaço, para além de seu tamanho, ano de construção ou localização? Estas foram algumas das perguntas que guiaram a formulação do projeto de pesquisa "Formas de habitar o centro, Salvador e Lisboa”, do qual estas páginas são um resultado parcial. $^{1}$

Nosso objetivo neste artigo é refletir sobre as relações entre espaço construído e práticas de habitar a partir do material etnográfico ${ }^{2}$ produzido em duas microlocalidades: o beco Camponesa e o pátio do Broas, situados nos centros de Salvador e Lisboa, respectivamente (figuras 1-4). Mediante o estudo destes dois locais, pretendemos refletir sobre a relação entre formas

I Projeto de estágio pós-doutoral desenvolvido no ISCTE - Instituto Universitário de Lisboa, entre agosto de 2016 e julho de 2017, sob supervisão da professora Graça Índias Cordeiro, estágio esse que incluiu a pesquisa etnográfica no centro de Salvador, em três becos e seis casarões ocupados por sem-teto, e em um pátio no centro de Lisboa. Este artigo, portanto, usa apenas uma parte do material empírico produzido pela pesquisa.

2 Entre 2016 e 2017, frequentei o beco da Camponesa (centro de Salvador) durante um ano e o pátio do Broas (centro de Lisboa) ao longo de três meses. Em ambos os campos, a pesquisa foi iniciada sem nenhum contato prévio ou conhecido no lugar. De forma tímida e um tanto ousada, ocupei um canto do pátio ou um degrau intermediário da escadaria do beco, desde o qual pude inicialmente observar o entrar e sair dos moradores, suas práticas, seus gestos, ouvir suas conversas, suas músicas. Como era de se esperar, fui logo interpelada. No beco e no pátio, eu explicava de forma resumida que era professora e pesquisava as "vizinhanças centrais", o tipo de "comunidade" que existia nesses espaços, como esses "bairros" eram antigamente e as mudanças que estavam acontecendo. Embora me esmerasse, usando uma linguagem local, claro que não os convencia. Incrivelmente, sua suspeição em relação à minha pessoa e objetivos foi vencida pelos livros: passei a carregar vários comigo, alguns dos quais de minha autoria, que fazia questão de mostrar para que acreditassem que eu era efetivamente uma professora - e não uma agente do governo ou uma espiã - que fazia uma pesquisa - e não um cadastro para fins duvidosos que poderiam prejudicá-los. Depois, com a confiança ou algo perto disso, minha presença ("a escritora”) se tornou familiar e pude ficar longas horas observando ou conversando, ouvindo ou trocando ideias que, depois, na fase da escrita, complementariam ou renovariam a literatura analisada sobre o tema. A etnografia é basicamente o processo que acabo de narrar: um tipo de aproximação, uma lente e uma relação com as pessoas que pretendemos entender, que busca adentrar ou mergulhar na vida cotidiana delas para emergir com dados e conceitos que permitam uma (re)leitura da realidade feita a partir do respeito à palavra e teoria dos próprios atores (cf. Montoya Uriarte 2012). 
urbanas caracterizadas pela estreiteza do espaço e construções contíguas (becos e pátios) e práticas de reunião e consideração entre vizinhos. ${ }^{3}$

Este interesse pela relação entre forma e conteúdo, morfologia e cultura, espaço e práticas, de fato, não é novo. Faz parte de uma antiga agenda da antropologia urbana iniciada por Edward Hall (1973) meio século atrás, que lamentavelmente pouco eco encontrou entre seus pares. Preocupado com as consequências das formas urbanas desiguais nas cidades norte-americanas - "nossas cidades estão criando tipos diferentes de pessoas em seus subúrbios, hospitais psiquiátricos, estabelecimentos penitenciários e zonas residenciais" (Hall 1973: 19), este autor propôs refletir sobre a importância do espaço construído nas práticas dos homens - "tendemos a passar por alto a influência que exerce a forma de um edifício sobre as pessoas que o habitam” (Hall 1973: 281). Mais recentemente, Michel Agier retomou este tema das formas urbanas e sua relação com as práticas de apropriação. Referindo-se aos becos do bairro popular da Liberdade, em Salvador, afirmou se tratar de formas com uma "potencialidade relacional" (Agier 2011: 109). Por sua vez, referindo-se aos cortiços da zona central de São Paulo, o sociólogo Lúcio Kovarick frisou a relação entre espaços diminutos - cubículos minúsculos - e forma de habitar "apertada", caracterizada por uma "sociabilidade do distanciamento" (Kovarick 2009: 272).

Iniciamos esta reflexão apresentando as características físicas dos becos soteropolitanos $^{4}$ e dos pátios lisboetas e fazendo uma breve explanação sobre suas origens e sua população residente. Em seguida, discorremos sobre o que chamamos de forma de habitar. Na terceira e quarta seções, respectivamente, apresentamos as características das formas de habitar encontradas no beco Camponesa e no pátio do Broas. Concluímos fazendo algumas considerações sobre as relações entre espaço construído e práticas de habitar.

3 Nas definições gerais, os vizinhos são descritos como aqueles que não são "nem íntimos, nem anônimos" (Mayol 2009: 43), ou "ao mesmo tempo muito próximos e muito longe, familiares e estranhos" (Haumont 2005: xvi). Parece-me, no entanto, que a natureza do laço social entre os vizinhos não pode ser especificada de antemão, pois, como este estudo demonstra, estas relações são o resultado de uma combinação de variáveis, tais como a morfologia dos lugares, a propriedade, a antiguidade no local, as possibilidades de mobilidade residencial, etc. A definição dada aqui é, portanto, genérica: vizinho é uma categoria social que se refere a pessoas relacionadas entre si pela contiguidade física de suas residências. Trata-se de uma relação espacial entre pessoas que advém do fato de morarem umas do lado das outras. É preciso frisar que esta relação emerge de uma aleatoriedade: elas não se relacionam porque se gostam ou porque assim o escolheram, fazem-no porque suas casas estão próximas ou coladas entre si, o que as leva à necessidade de partilhar alguns espaços físicos (entradas, calçadas), visuais (janelas) ou sonoros. A forma que adquire esta relação é, insistimos, bastante variada.

4 Soteropolitano designa o natural ou habitante de Salvador da Bahia. 

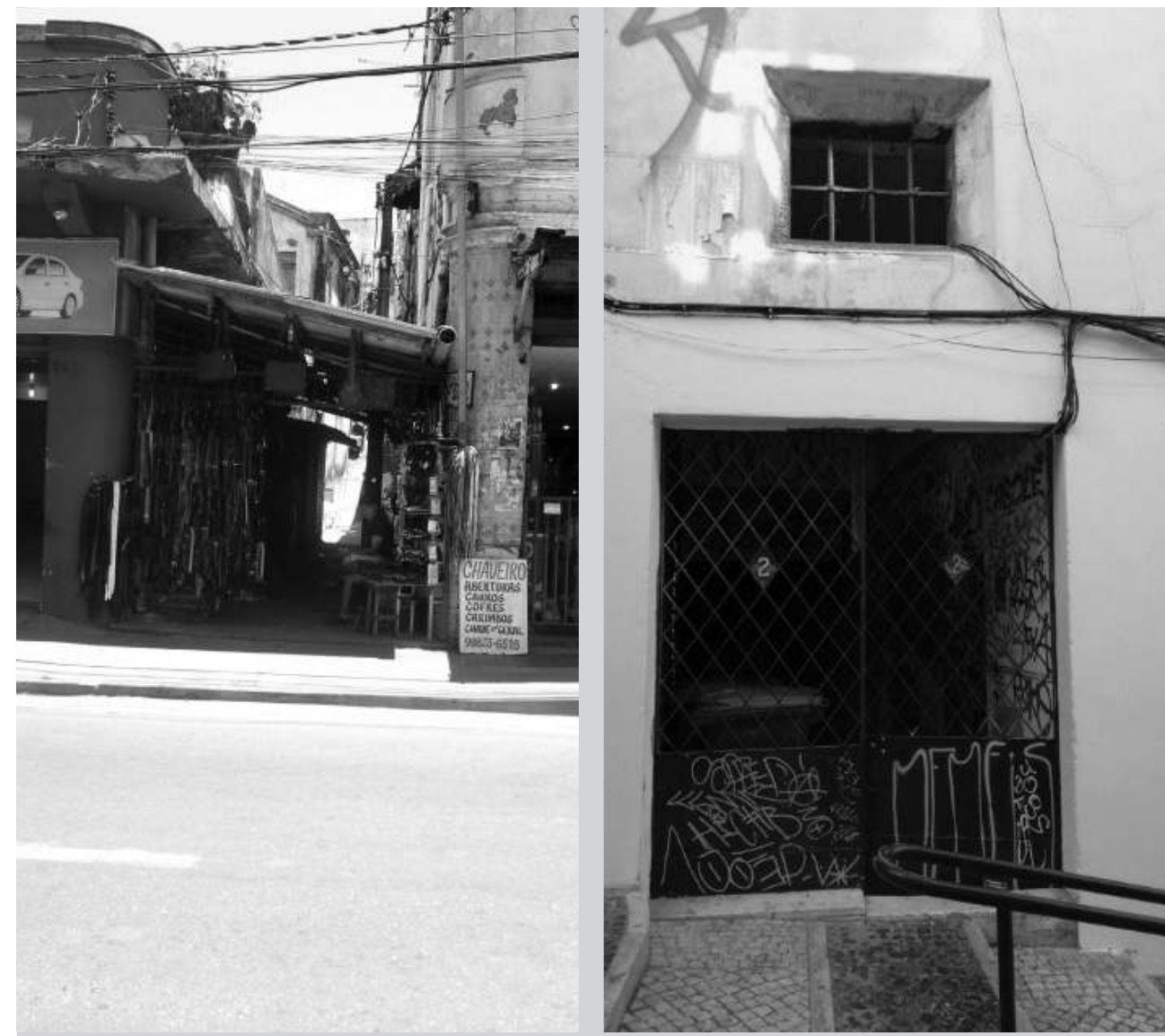

Figura 1 - Entrada do beco Camponesa (Salvador, Bahia, Brasil).

Figura 2 - Pátio do Broas (Lisboa, Portugal).

Foto: Urpi Montoya Uriarte, 2017

Foto: Urpi Montoya Uriarte, 2017

\section{BECOS E PÁTIOS, SALVADOR E LISBOA}

Becos e pátios são palavras com muitas acepções. Talvez a mais comum seja a de espaços específicos: um tipo de rua - estreita, geralmente sem saída - e um tipo de praça - no interior de edifícios. Becos e pátios podem ser também termos que se referem a tipos de habitação popular ou ambientes de residência dos setores populares, caracterizados pela estreiteza do espaço. É este o sentido que aqui damos a estas palavras.

Em Salvador, primeira capital do Brasil e hoje quarta maior cidade do país com quase três milhões de habitantes em sua região metropolitana, os becos são ambientes semifechados compostos por pequenas casas alinhadas, geminadas, com um corredor estreito que separa dois alinhamentos paralelos de casas 


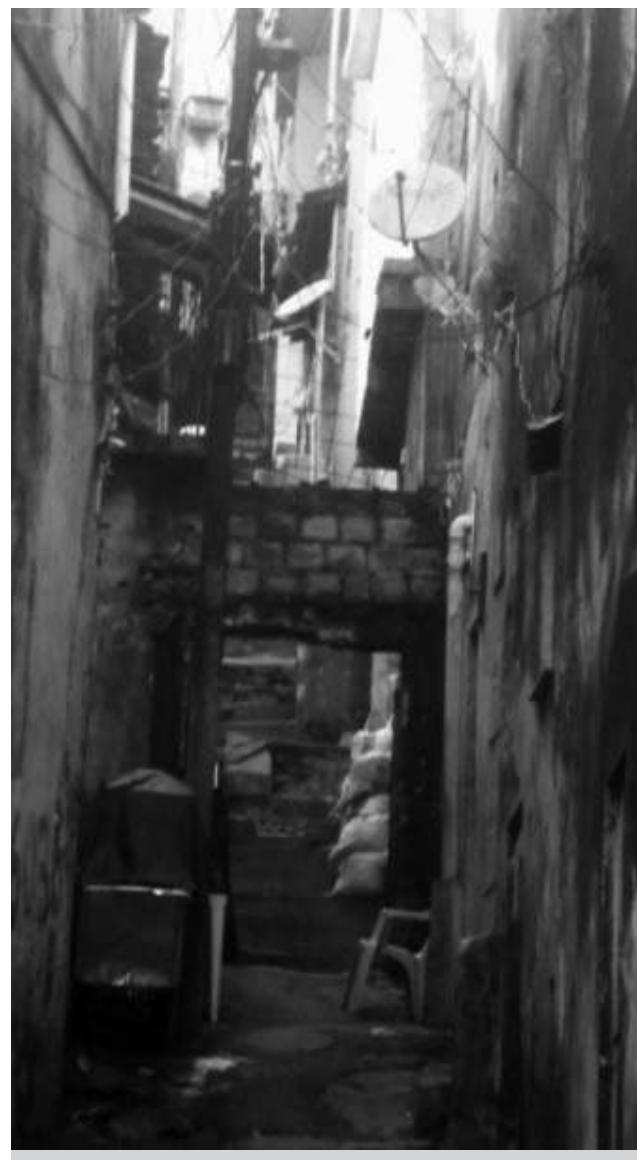

Figura 3 - Os corredores que levam até o conjunto de casas do beco Camponesa (Salvador). Foto: Urpi Montoya Uriarte, 2017

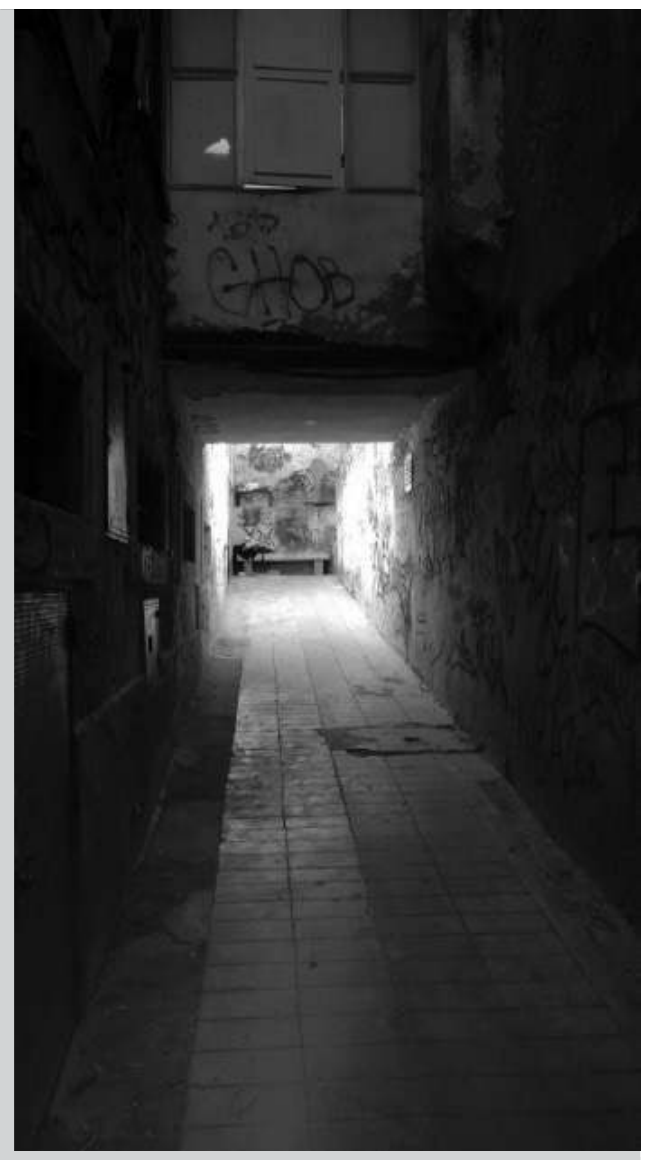

Figura 4 - Passagem que leva às habitações do pátio do Broas (Lisboa)

Foto: Urpi Montoya Uriarte, 2017

cujas portas ficam umas em frente das outras. Trata-se de uma rua muito particular, por ser muito estreita e de uso quase privado de seus moradores. Nessa cidade, este ambiente particular de moradia é também chamado, muito paradoxalmente, de "avenida", assim definida por Cardoso: conjunto de "pequenas casas conjugadas voltadas para uma rua de pedestres, articulada perpendicularmente com o logradouro principal" (1991: 142). Não sem razão, o escritor Jorge Amado (1983: 72) chamou a atenção deste nome "pomposo" para tão simples "correr-de-casas".

Por sua vez, em Lisboa, chama-se pátio ao ambiente de habitação popular, igualmente coletivo e semifechado, construído na parte de trás dos prédios e aos quais se adentra mediante um corredor. Em palavras de Cordeiro (2014: 473), pátios são "pequenos conjuntos habitacionais miseráveis que foram 
surgindo em certos lugares intersticiais da cidade - espaços vazios entre prédios, ou no interior de palácios e conventos, quintais, logradouros, becos, etc. - caracterizados pela falta de condições de habitabilidade, pela fome e pela doença, e moralmente conotados pelo vício, o crime, a marginalidade".

Nas "avenidas", há efetivamente um beco ou rua estreita separando as fileiras de casas. Nos pátios, as casas são construídas ao redor de um espaço central. A forma do terreno em ambos os espaços é, pois, diferente: os pátios tinham uma forma quadrangular, advinda de um lote irregular que promovia a construção das casas acompanhando suas paredes, deixando no centro um espaço vazio (Teixeira 1996: 63); as "avenidas", por sua vez, eram construídas num terreno retangular profundo, porém de largura estreita. Apesar desta diferença física, as semelhanças sociais e históricas entre becos/avenidas e pátios são bastante significativas.

Em ambos os casos, as casas são contíguas, com espaços exíguos, escuros, úmidos, sem ventilação e, inicialmente, sem serviços higiênicos individuais. Até hoje, a maior parte das casas de "avenidas" e pátios tem aproximadamente $25 \mathrm{~m}^{2}$ e apresenta problemas sérios de umidade e infiltração. Em becos e pátios, as casas partilham um espaço de uso coletivo (corredores ou pátios). Nas duas cidades, estas formas físicas surgiram na segunda metade do século XIX, predominantemente nos espaços centrais, antigos. Como os pátios (Cordeiro 1997, 2014), as "avenidas" foram construídas nos espaços vagos, laterais ou fundos de edifícios particulares, o que explica sua intersticialidade e invisibilidade. Partilham igualmente a condição de margem ou liminaridade, isto é, de indefinição entre logradouro público e privado, rua e casa, dentro e fora. Becos/ avenidas e pátios foram do mesmo modo empreendimentos de agentes individuais que viram neles a possibilidade de lucrar com o aluguel de casinhas para as classes trabalhadoras que, naquele período, cresciam aceleradamente nestas cidades, fruto das imigrações internas promovidas ora pela industrialização, em Lisboa (Teixeira 1996), ora pela alforria ou fim da escravidão, em Salvador (A. L. R. Costa 1989). Em ambos os casos, seus construtores foram os mesmos setores médios-baixos ou empobrecidos, com pouco capital e cujo investimento foi processual e de escassa envergadura, razão pela qual a maioria de becos/avenidas ou pátios são relativamente pequenos e muito mal equipados (Ribeiro 1997). Por fim, tanto em Salvador quanto em Lisboa, até o início das primeiras décadas do século XX, os poderes públicos pouco ou nada intervieram em sua formatação e exigência de condições a serem oferecidas. Foram as epidemias que obrigaram as autoridades a olhar para estes espaços, sendo condenados pelos higienistas como focos de infecção e periculosidade para toda a cidade (David 1996; MOPCI 1905).

Vale ressaltar que becos/avenidas e pátios não constituíram a principal forma de habitação popular. Em Salvador, na primeira metade do século XX, foram os cortiços - antigos casarões coloniais subdivididos - que predominaram e, na 
capital portuguesa, nesse período, os edifícios multifamiliares e as vilas proletárias. Na segunda metade desse século e até os dias de hoje, em Salvador, a habitação popular majoritária se encontra nas chamadas "invasões" na periferia e bairros populares consolidados que delas decorreram. Junto com os sobrados e os cortiços, os becos compõem o que a urbanista Ângela Gordilho (2008) designou de "ocupação antiga". Trata-se de formas remanescentes do casario colonial que, em 1991, representavam apenas 8,45\% do total da área ocupada com predominância habitacional da cidade de Salvador (Gordilho 2008: 209). Lamentavelmente, não contamos com informação atual sobre a área ocupada pelos pátios na cidade de Lisboa. Sabemos, contudo, o número absoluto destes em inícios do século XX:

“[...] esta forma de habitação nunca foi construída à escala das ilhas do Porto. Em 1905, existiam 233 pátios em Lisboa, totalizando 2.278 habitações e alojando 10.487 pessoas. Na mesma altura, existiam no Porto 1.048 ilhas, com 11.129 casas e cerca de 50.000 pessoas, isto é, com menos da metade da população de Lisboa (em 1900, o Porto tinha 167.955 habitantes e Lisboa 356.009), o Porto tinha quase cinco vezes mais pessoas a viver neste tipo de habitação que Lisboa" (Teixeira 1996: 63).

Os becos soteropolitanos e os pátios lisboetas são, hoje, espaços habitacionais residuais, simbolicamente pouco significativos para o imaginário coletivo da cidade.

Além da forma física, das condições históricas de seu surgimento e da irrelevância simbólica destes tipos de habitação popular, uma outra semelhança importante deve ser frisada entre estes dois espaços: seus moradores partilham um mesmo perfil socioeconômico. Quem habitava e quem habita hoje os becos do centro da cidade de Salvador e os pátios do centro de Lisboa são os setores que compõem as classes populares, isto é, aquele

"continuиm de posições e práticas sociais, que aproximam operários, trabalhadores precarizados em múltiplas funções de concepção, produção e distribuição, assalariados subalternos de execução, pequenos comerciantes e outros trabalhadores independentes, camponeses, todos em situação socialmente subordinada, quer em termos materiais, quer em termos simbólicos" (Lopes, Louçã e Ferro 2017: 295).

Segundo Ana de Lourdes Ribeiro da Costa (1989) e as informações coletadas com os moradores mais antigos dos becos pesquisados, na primeira metade do século Xx moravam neles pessoas com baixos e incertos rendimentos, vivendo da "viração": trabalhadores do porto, artesãos (sapateiros, ferreiros, etc.), carregadores, vendedores de rua e lavadeiras. No caso do pátio do 
Broas, eram pessoas ligadas às atividades do rio e do porto: estivadores, pescadores e varinas. Nos dias de hoje, as pessoas em idade laboral que habitam os becos/avenidas do centro de Salvador estão em grande parte desempregadas, subempregadas ou são trabalhadores informais por conta própria, ou pessoas que recebem auxílio de subsistência do governo (bolsa família). Em Lisboa, no pátio do Broas, a grande maioria da população economicamente ativa é assalariada, porém, parte de um sistema de superexploração, fator que, como veremos, em muito contribui para uma forma de habitar diferente da encontrada nos becos da Baixa dos Sapateiros, em Salvador.

\section{FORMAS DE HABITAR}

Nossa perspectiva sobre o habitar advém de um diálogo entre a antropologia e a filosofia de inspiração fenomenológica. Difere de visões que limitam o habitar a uma "qualidade do ambiente onde se vive" (Gordilho 2008: 14), daquelas que priorizam seu aspecto representacional - "habitar não consiste essencialmente em ocupar um espaço e delimitá-lo, mas em significar um lugar" (Rojas 2013: 20) - ou das que entendem o habitar como "a relação estabelecida por uma pessoa ou família com a casa, uma relação que pode ser analisada através do tempo passado na casa, do interesse que a mesma desperta nos seus moradores e sobretudo das práticas que aí são desenvolvidas" (Bernard, apud Pereira 2016: 20). O conceito de habitar que aqui propomos vai além das noções de habitat, habitabilidade ou habitação e tem sua inspiração inicial nas ideias de Henri Lefebvre.

Em $O$ Direito à Cidade, trabalho escrito num contexto em que a cidade de Paris passava por profundas transformações - remodelações, gentrificações, renovações e construção de imensos prédios de habitação social -, Lefebvre (1991 [1969]) propôs superar a noção de habitat como simples espaço físico e recuperar a ideia de habitar, entendida como uma relação específica do morador, usuário ou citadino com o espaço - uma relação versátil, plástica, que promove ou permite sua apropriação. Em Do Rural ao Urbano (Lefebvre 1970), o autor reiterou esta necessária relação entre o habitar e a apropriação do espaço: "habitar, para o indivíduo, o grupo, significa apropriar-se de alguma coisa. Não dele ter a propriedade, mas fazer dele sua obra, colocar nele sua marca, modelá-lo" (Lefebvre 1970: 222). Em sua concepção, a apropriação era, pois, uma qualidade intrínseca do habitar, que se desdobrava em práticas tais como a transformação, modificação, reinvenção, adequação, etc. Assim, habitavam-se os pavilhões - aquelas casas independentes umas das outras que proliferaram na periferia de Paris desde meados do século XIX -, pois eles permitiam uma real apropriação do espaço; em contraposição, os edifícios enormes de habitação social que estavam sendo construídos na década de 1950, fruto da racionalidade estatal, só promoviam coações e negavam a necessária plasticidade do 
habitar - eram apenas habitat (Lefebvre 1991 [1969]: 23), isto é, espaço construído sem conteúdo humanizado.

O conceito de habitar de Lefebvre dialogava estreitamente com outro conceito muito presente em suas reflexões: o de obra. Em contraste com o produto, por definição algo pronto e acabado, feito por outros num processo de alienação do produtor em relação ao seu trabalho, a obra é feição individual do morador e citadino, peça única porque fruto de necessidades particulares. A apropriação permitia que o produto virasse obra, daí a importância desse conceito, que concebeu como "um dos mais importantes que tenham nos legado os séculos de reflexão filosófica” (Lefebvre 2001 [1966]: 17), pois é o mecanismo que permite habitar espaços construídos por outrem.

A relação entre habitar e apropriação, bastante enfatizada no prólogo de Lefebvre ao livro L'habitat pavillonaire, incorpora outros elementos em $O$ Direito à Cidade. Neste, habitar supõe também práticas de participação, integração e reunião. Referindo-se ao bairro do Marais antes de 1848, este autor escreveu: "'habitar' era participar de uma vida social, de uma comunidade, de uma aldeia ou cidade. A vida urbana detinha, entre outras, essa qualidade, esse atributo. Ela deixava habitar, permitia que os citadinos-cidadãos habitassem" (Lefebvre 1991 [1969]: 21). Desse modo, neste texto, "habitar é [...] inventar, criar o seu espaço quotidiano e ser inserido num amplo círculo de relações, de paisagens familiares e, no entanto, sempre a descobrir" (Clavel 2015: 151).

Décadas antes de Lefebvre, Heidegger (s.d. [1954]) já havia se detido na caracterização das relações que o habitar supõe, também num contexto bastante particular, o da Alemanha do pós-guerra. Em sua famosa palestra intitulada "Construir, habitar, pensar" (Heidegger s.d. [1954]), o filósofo provocou os arquitetos perguntando-lhes que orientação deveria seguir a reconstrução das cidades devastadas. Antes de edificar, propôs ele, era imprescindível que a arquitetura se perguntasse filosoficamente sobre o significado do habitar:

"Considerando-se a atual crise habitacional, possuir uma habitação é, sem dúvida, tranquilizador e satisfatório; prédios habitacionais oferecem residência. As habitações são hoje bem divididas, fáceis de se administrar, economicamente acessíveis, bem arejadas, iluminadas e ensolaradas. Mas será que as habitações trazem nelas mesmas a garantia de que aí acontece um habitar?" (Heidegger s.d. [1954]: 1)

Ao dizer que "somente se formos capazes de habitar seremos capazes de construir", Heidegger alterou a ordem dos fatores e elevou o habitar a categoria básica, central, estruturante, pois ela supunha algo muito maior, transcendental e complexo, algo que envolvia todas as características humanas do 
ser (divino e mortal). Entendia o habitar nada menos do que como a forma de ser humano no mundo, isto é, integrando elementos, relacionando coisas, reunindo componentes. Este entendimento advém de sua concepção de ser como um ser-no-mundo, ou seja, um ser em relação intrínseca com o mundo, no mundo; um ser centrífugo que precisa se estender, lançar raízes para fora de si. Só se é ser, pois, habitando. Embora a história da humanidade tenha consistido num contínuo desaprendizado do que é habitar, essa era, para ele, a essência humana.

Partindo do sentido etimológico de habitar, Heidegger revelou a relação entre as palavras construir e habitar: na medida em que construir significava respeitar/resguardar a essência das coisas e que esta essência era a de reunir, habitar e reunir eram uma coisa só. Assim, nada mais longe do habitar do que o ocupar ou o apenas estar em ou permanecer em cima, na superfície ou sobre um espaço. Habitar é enraizar-se com as coisas e seres de um espaço. Heidegger entendia por enraizamento uma relação de expansão, um para-fora que podemos traduzir como um estar-junto, em-meio-a, conectado-com, entrelaçado-a, envolvido-com, junto-a, enredado-em. O filósofo usa o verbo demorar-se: "Os mortais jamais o conseguiriam se habitar fosse tão-só uma de-mora sobre a terra, sob o céu, diante dos deuses, com os mortais. Habitar é bem mais um demorar-se junto às coisas" (Heidegger s.d. [1954]: 4). Desta maneira, na visão heideggeriana, o espaço habitado é aquele que promove a reunião, o enraizamento, o demorar-se junto aos outros. Como em Bachelard (1998), o habitar de Heidegger se compõe de atitudes profundas, oníricas, poéticas.

O mesmo sentido de reunião contido no conceito de habitar de Heiddeger e Lefebvre aparece na reflexão sobre o tema proposta pelo antropólogo contemporâneo Tim Ingold (2002). Influenciado pela fenomenologia, Ingold entende que o indivíduo está no mundo, não sendo um ser autossuficiente confrontado com o mundo exterior. Para ele, "estar-no-mundo" significa estar vivo, ou seja, necessariamente em movimento, em estado de se fazer, em crescimento, em processo. O habitar é esta imersão, este necessário e inegável processo de envolvimento de seres, corpos, coisas, materiais. Humanos e não humanos habitam na medida em que estabelecem relações com os seres vivos e os objetos que nele vivem e se desenvolvem, relações que são constituídas no dia a dia mediante atividades/tarefas ou, como prefiro chamá-las, mediante práticas.

Assim, o conceito de habitar que propomos soma as contribuições de Heidegger, Lefebvre e Ingold para entendê-lo como uma relação de envolvimento ou enraizamento de todos os seres (humanos e não humanos) e objetos que compõem um espaço. Esta relação se desdobra ou materializa em práticas diversas, que veremos nas seções seguintes, criando configurações particulares que chamamos de formas de habitar. 


\section{COM VIZINHOS: O HABITAR NA “AVENIDA” CAMPONESA, BAIXA DOS SAPATEIROS, CENTRO DE SALVADOR}

A "avenida" Camponesa é um beco relativamente novo localizado na parte central de uma importante rua comercial do centro antigo de Salvador, chamada Baixa dos Sapateiros. Como muitos outros becos, esta "avenida" se compõe de um corredor perpendicular à Baixa, que acompanha todo o declive de uma colina empinada. São 37 degraus, alternados com pequenas rampas e descansos de largura e altura bastante irregulares (figura 5). A entrada fica entre uma padaria e uma loja e nela se localizam vários vendedores ambulantes que penduram suas mercadorias, o que dificulta ainda mais a percepção da existência deste beco aos olhos dos transeuntes.

Em termos históricos, trata-se de uma "avenida" recente, surgida na década de 1970, isto é, praticamente um século após a maior parte dos becos existentes da área. Uma planta de 1956 demonstra a existência do beco nesse ano, mas sem evidência das casas construídas que hoje encontramos nele; era um conjunto de quintais. Um morador antigo nos informou que 12 lotes foram vendidos na década de 1960 no lado direito do beco e que seus proprietários passaram a construir pequenas casas de apenas dois cômodos. Nas décadas seguintes, foram edificadas casinhas de forma irregular (no que o linguajar popular chama de "invasões") no lado esquerdo e, depois, muitas outras nos fundos delas e nos fundos destas também, aproveitando um dos poucos terrenos baldios da região. Assim, diferentemente dos becos antigos, este contém grande número de casinhas e muitos becos dentro do beco.

Segundo nosso próprio levantamento, dos 42 terrenos existentes na "avenida” Camponesa, 13 são subdivididos, totalizando 63 unidades familiares. São aproximadamente 170 moradores, com 2,7 pessoas por unidade familiar. Dessas unidades familiares, 56 consideram a casa de sua propriedade e apenas sete a têm alugada. Os poucos inquilinos que há no beco pagam em média 500 reais por dois quartos pequenos, sala diminuta, banheiro e cozinha de espaços igualmente reduzidos. Poucas casas mantêm-se térreas, o que indica um ritmo acelerado de crescimento vertical dos imóveis. ${ }^{5}$

A "avenida" Camponesa é habitada de uma forma particular, que denomino habitar com vizinhos. O engajamento, reunião ou enraizamento entre eles se evidenciam em três tipos de práticas. A primeira, e talvez a mais evidente, é a prática de as casas "avançarem", termo nativo para se referir à expansão ou crescimento da casa, preenchendo todo o lote (frente, lado e fundos) e indo além (adentrando no que costuma ser chamado de espaço

5 No câmbio de meados de 2018, 500 reais equivalem aproximadamente a 135 euros. O salário mínimo equivale a mais ou menos 240 euros. 


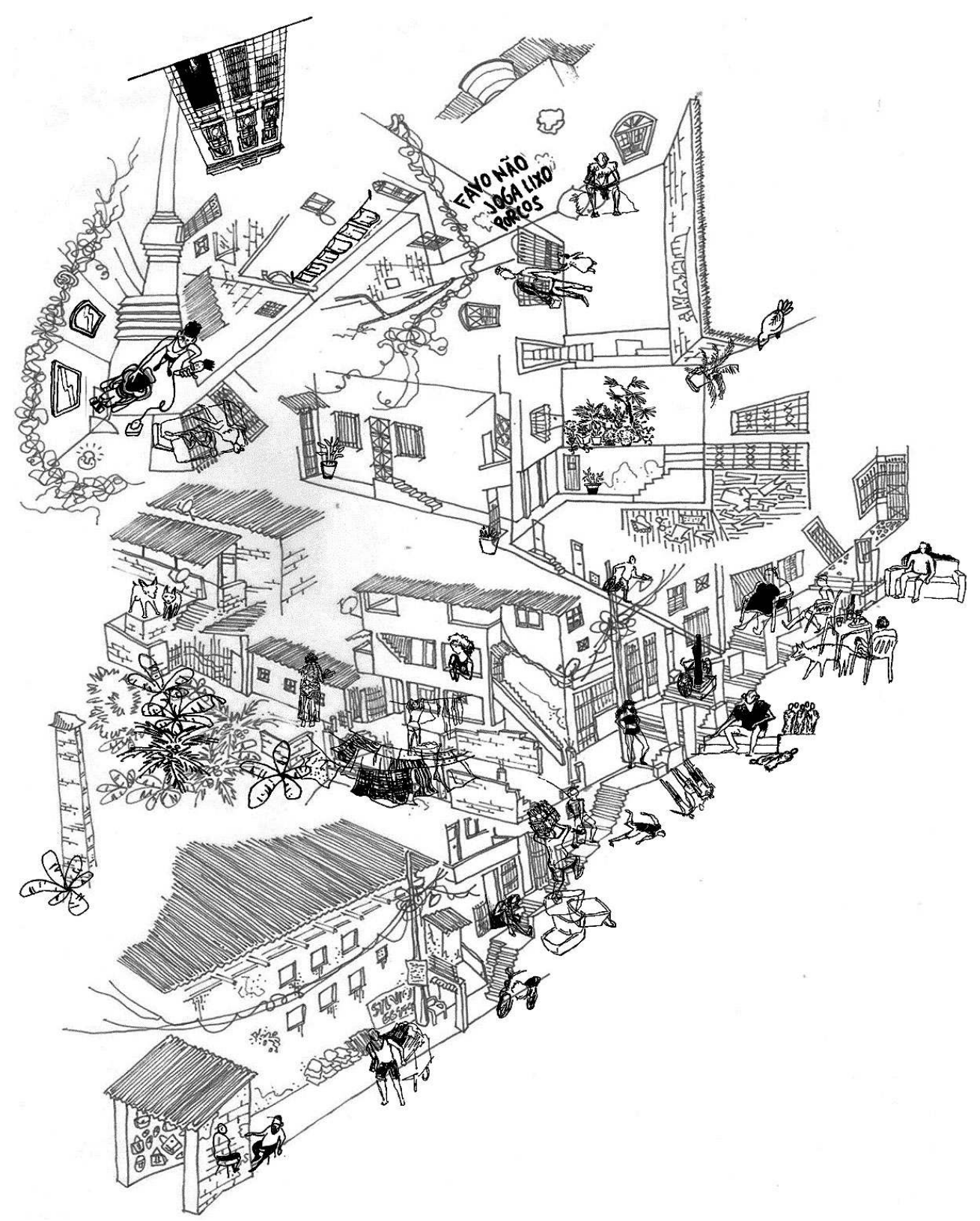

Figura 5 - Croqui da “avenida” Camponesa (Salvador). Desenho: Elaboração de Bruno Fernandes, 2017.

Na parte inferior, a entrada do beco. Inicialmente, na década de 1970, a "avenida" consistia em apenas um corredor com casas do lado direito. Depois, foram construídas casas no lado esquerdo e, em seguida, todo o lado posterior foi sendo "ocupado" e construído, dando lugar a um labirinto de becos e casinhas. 
público). ${ }^{6} \mathrm{O}$ "avançar" da casa - ou, dito de forma lefebvriana, a apropriação-transformação que seus moradores promovem nela - acompanha os distintos estágios e tipos de configuração familiar pelos quais passa a família na população de baixa renda, tais como os nucleares incompletos, os nucleares compostos e os arranjos extensos (Hita 2014).

As práticas de "avançar" promovem engajamentos entre os vizinhos, na medida em que propiciam proximidades cada vez maiores entre si. A cada janela aberta por um morador fica maior a intimidade exposta do vizinho. A cada espaço livre ocupado por alguém se reduz a separação entre as casas. Os espaços já exíguos do beco, acanhados e estreitos, ficam cada vez mais juntos. Num espaço assim configurado, é impossível não se cruzar, ouvir, ver, conhecer, ficar sabendo uns dos outros. Tudo ou quase tudo se ouve e, em alguns casos, até se vê, ou pela porta (constantemente aberta) ou pela janela (daí a recorrência de mantê-las fechadas).

Mais importante ainda do que a proximidade física, o "avançar" das casas promove a consideração entre vizinhos, pois, para que as casas cresçam, é necessário que os vizinhos concordem, permitam ou autorizem essa expansão. O que chamo de habitar com vizinhos supõe uma disposição de abertura para entender as necessidades dos vizinhos e promove uma relação entre eles. Sem esta disposição e relação, não seria possível a cessão de lajes para a construção no nível superior de uma casa, ou a edificação de escadas externas que garantam o acesso independente às unidades construídas nos pavimentos superiores e que ocupam parte dos corredores estreitos dos becos; não seria possível ainda a abertura de becos que viabilizam o ingresso às unidades construídas nos fundos da casa, nem o consentimento para que o vizinho abra janelas na laje do outro. Estes são alguns dentre muitos exemplos possíveis da necessidade de negociar o espaço construído com os vizinhos, pois em todos os casos a consequência é a diminuição da ventilação, luminosidade e espaço de trânsito. O aproveitamento máximo do potencial construtivo exige, pois, acordos que legitimem os processos construtivos (Lima 2016).

Uma segunda prática de reunião que compõe o habitar com vizinhos encontrado na "avenida" Camponesa fica evidente no cenário constante das portas abertas. Neste beco, a exígua distância entre vizinhos não promove a distância psicológica ou emocional necessária, segundo Simmel (1967), para o convívio. Não há aqui vizinhos blasés, mas vizinhos que, pelo contrário, deixam suas portas abertas, ficam nas janelas olhando a vida dos outros, deixam suas conversas, cantos ou gritos chegarem livremente aos ouvidos dos outros habitantes. A prática de deixar as portas abertas é possível pela existência de

6 Vale salientar que esta prática é muito comum nos bairros populares de Salvador, seja no centro da cidade ou fora dele, como no bairro Saramandaia (Lima 2016), ou no interior do estado da Bahia (Pina-Cabral e Silva 2013). 
duas portas na grande maioria das casas: à porta sólida acrescenta-se uma outra, vazada, de ferro. A primeira fica aberta e a segunda fechada, resguardando-se assim as necessidades de segurança. Por entre as grades vaza o ar e a luz, bastante necessários aos espaços exíguos e escuros que são as casas dos becos/avenidas. Mas não apenas isso: pelas grades, o beco entra na casa e a casa se abre ao beco.

A circulação de pessoas, olhares, cheiros e sons torna os becos/avenidas da Baixa dos Sapateiros contextos relacionais densos. Esta circulação faz parte, a meu ver, de uma concepção de casa não como uma instância isolada, independente, um mundo à parte onde se entra e vigoram regras autônomas, mas de uma realidade aberta ou semiaberta, de um lugar onde "cabe sempre mais um". Nesse sentido, nada mais longe dessa realidade do que a famosa oposição entre casa e rua, tão salientada na leitura brasileira sobre o convívio urbano (Freyre 2004; DaMatta 1985). A realidade encontrada nos becos/avenidas corresponde mais a uma produção historiográfica dos espaços populares que destaca o "intenso entra-e-sai nas portas, uma diluição continua de espaços - algo mais necessário à dura sobrevivência improvisada dia a dia pelos muitos pobres e miseráveis que povoavam as cidades brasileiras do que as ilusões de reclusão e discrição propaladas pelas elites" (Marins 2006: 138). Esse "entra-e-sai" de uma casa foi assim registrado em meu caderno de campo:

"A casa de Sara é pequena. Na sala cabe uma mesa redonda, um sofá de três lugares, uma estante com a televisão e vários objetos de decoração, além de um tapete. Como em muitas outras casas, as janelas estão sempre fechadas, a luz sempre acesa e o ventilador sempre ligado. O tom de tudo é verde, cor dos sapos que ela adora e coleciona em todos os tamanhos e modelos, espalhados em todos os cômodos. A sala e a cozinha não têm divisórias. A cozinha é pequeninha (tem um fogão de quatro bocas, uma geladeira, um micro-ondas e estantes) e sempre me pergunto como ela consegue cozinhar ali para servir o seu bar, que oferta pratos diversos. Nesse ambiente, transitam os habitués da casa, a grande maioria parentes-vizinhos ou vizinhos-amigos. Muitos chegam e vão rápido, outros ficam mais um pouco. Tem gente assistindo televisão no sofá, gente em pé, Sara cozinhando. Mas poucos ficam muito tempo. É um entra-e-sai que acompanha a rotina atarefada de todos e os momentos de descanso-prosa que se dão" [caderno de campo, 2016].

As portas abertas reúnem os vizinhos ao permitir a circulação de cenas, conversas, músicas; propiciam visitas ou paradinhas para trocar uma prosa; convidam olhares curiosos e o interesse pela vida do vizinho; permitem acompanhar o cotidiano dos outros e estar sempre informado. Enfim, garantem o estar com, a reunião e o engajamento entre os vizinhos de um mesmo beco. Não em vão, 
a porta era a figura favorita de Simmel: "a porta ilustra de maneira mais clara até que ponto separação e reaproximação nada mais são do que dois aspectos do mesmo ato" (Simmel 1996: 12).

Mas não são apenas olhares, sons, informações e conversas que circulam por entre as casas da "avenida" Camponesa. Circulam também parentes que são vizinhos ou vizinhos que se tornaram parentes: as casas são aparentadas. O aparentamento das casas - as casas articuladas entre si - é a terceira prática que conforma o habitar em vizinhança, embora seja preciso frisar que ela não é privilégio do habitar dos becos. ${ }^{7}$ Encontramos casas aparentadas num mesmo terreno (com parentes, sanguíneos ou não, morando em andares diferentes), num mesmo beco e entre becos diferentes. Ao fazer parte de uma rede de casas aparentadas, as refeições podem ser feitas em qualquer uma delas; as visitas, mesmo rápidas, são constantes; os empréstimos ou a ajuda mútua para a faxina ou ocasiões especiais são frequentes; o cuidado dos filhos ou outros favores são permanentemente solicitados.

Para concluir esta seção é preciso salientar que o habitar não se compõe apenas de proximidades alegres, de circulações pacíficas, de reconhecimentos familiares ou engajamentos harmônicos. Se está-junto, em meio-a e entrelaçado-com mediante práticas igualmente conflituosas, problemáticas ou reprovadas. A forma de habitar com vizinhos não está livre de insatisfações, divisões, rejeições e, principalmente, medo.

Enquanto que em outros becos ouvi muitas reclamações dos moradores queixando-se dos vizinhos barulhentos, sujos ou que não sabem educar seus filhos, na "avenida" Camponesa, paradoxalmente, ninguém me falava em problemas. Entendi o silêncio sobre o tema quando um frequentador do beco me deu a seguinte dica: "A lei aqui é não pode ouvir, não pode falar, não pode ver". Com efeito, nesse beco/avenida, o problema do tráfico de drogas parece ser mais sério do que nos outros e, precisamente por isso, a "lei do silêncio" que ele impõe é mais fielmente seguida, fazendo-se evidente nas reticências nas falas dos interlocutores ou no sigilo, frases truncadas e mudanças repentinas de tema. Nos últimos anos, algumas mortes, várias prisões e muitas incursões policiais têm afetado o cotidiano desta "avenida", gerando apreensão, coibindo as conversas, reprimindo o costume de ficar nas portas e janelas. Entretanto, por enquanto, na medida em que o comércio de drogas constitui a forma de vida de uma minoria de seus habitantes, ainda se habita com vizinhos na Camponesa.

7 Os estudos de Marcelin (1999), Agier (2011), McCallum e Bustamante (2012), Pina-Cabral e Silva (2013), Hita (2014) e Lima (2016) têm verificado, em bairros diversos de população de baixa renda de Salvador e outras cidades baianas, a mesma existência de uma rede de casas próximas e aparentadas, nas quais circulam refeições, emprestam-se objetos e trocam-se favores. 
SEM VIZINHOS: O HABITAR NO PÁTIO DO BROAS, BICA, CENTRO DE LISBOA

O pátio do Broas se encontra na parte baixa do bairro da Bica, na parte de trás e na lateral de um grande prédio cuja entrada se localiza na rua de São Paulo, que fica perto do mercado da Ribeira, da igreja e do largo de São Paulo e do Cais do Sodré (figura 6). O prédio, cujas origens remontam ao século XVI, tem quatro pavimentos, com 12 apartamentos, em sua maior parte pequenos. Tudo indica que, na segunda metade do século XIX, esse prédio ganhou duas ampliações: na lateral, um conjunto de seis apartamentos, e, nos fundos, um conjunto de 17 casinhas erguidas ao redor de um pátio. São estas casinhas que conformam o pátio do Broas, cuja entrada se faz pela calçada da Bica Grande (perpendicular à rua de São Paulo).

Em contraste com as casinhas da "avenida" Camponesa, onde a maior parte dos imóveis é propriedade de seus moradores, as do pátio do Broas pertencem todas a dona Manuela, uma senhora de 87 anos que as herdou de seu falecido marido. As casas são muito pequenas e a umidade e as infiltrações nelas são enormes. Os que ganham pouco e precisam morar no centro pela proximidade de seus locais de trabalho veem nessas casinhas uma grande oportunidade, apesar de os 400 euros de aluguel representarem uma enorme percentagem do salário mínimo que ganham (em 2017, pouco mais de 500 euros).

Neste pátio, habita-se sem vizinhos. Existem relações - reunião, entrelaçamento e enraizamento -, mas não entre vizinhos, e não se efetuam no espaço coletivo. As pessoas passam pelo pátio, não ficam nele. Entram e saem de

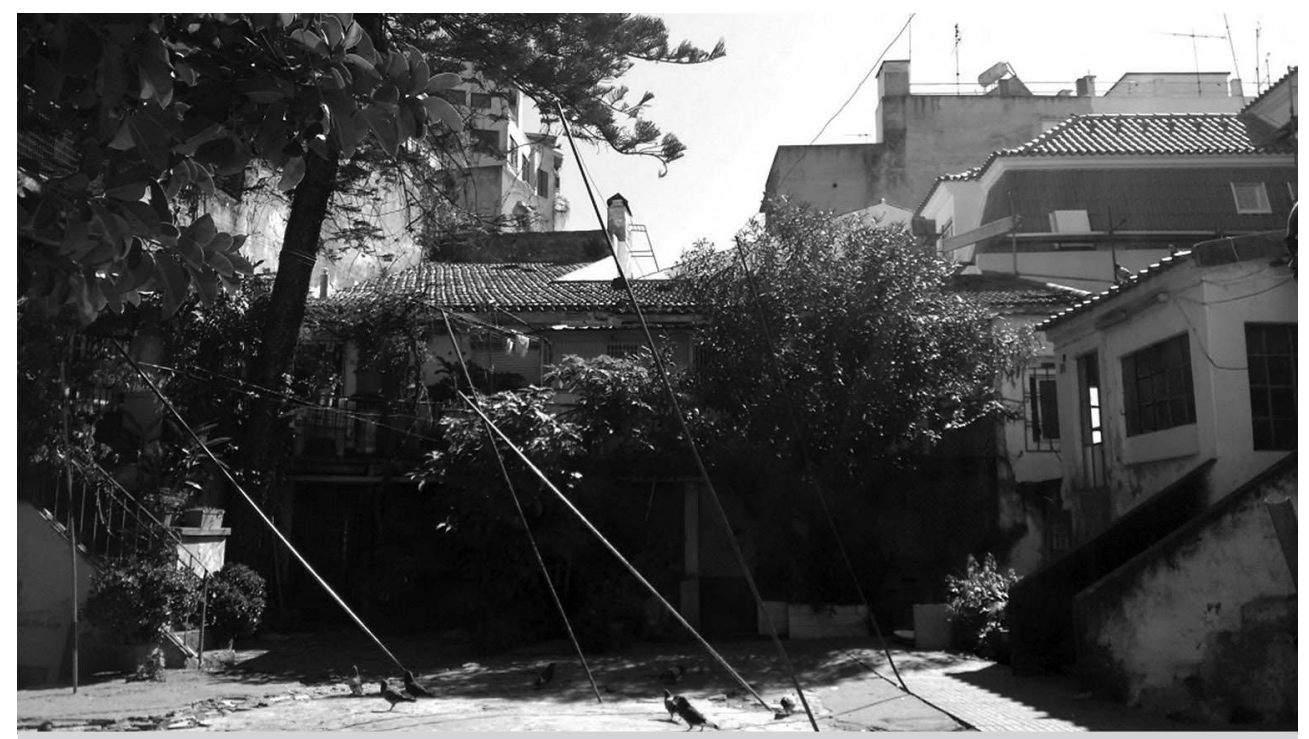

Figura 6 - Pátio do Broas (Lisboa). Foto: Urpi Montoya Uriarte, 2017 
suas casas em silêncio e, quando se cruzam, cumprimentam-se com um polido "bom dia" ou fazendo um gesto com a cabeça.

Nem sempre foi assim. Em finais da década de 1980, Leite e Vilhena (1991) descreveram a vida de um pátio da seguinte forma:

"No pátio substitui-se a casa pela rua e a rua pela casa: se o tempo promete, os habitantes passam as horas mortas sentados numa cadeira ou banco no terreiro; uma mulher prepara a comida para o gato, outra alimenta os seus periquitos; a avó dá de comer ao neto, que guarda durante o dia; nos tanques, lava-se a roupa; a costura e o tricô são a oportunidade para mais um dedo de conversa; um velhote apanha o fresco da tarde, as pernas já não o deixam ir à taberna mais próxima; as crianças jogam a bola, brincam com carros e bonecas, andam até de bicicleta. As portas, uma janela ou simplesmente o postigo estão sempre abertos para o pátio" (Leite e Vilhena 1991: 105-106).

A calçada da Bica Grande - conhecida como "escadinhas" - foi descrita na década de 1990 por Cordeiro de forma semelhante:

“[...] a familiaridade descontraída com que as crianças brincam nas escadinhas sob a atenção escondida das muitas mulheres presentes, nos pequenos objectos abandonados na soleira das portas abertas, apenas protegidas por um cortinado, nos largos lençóis e toalhas que esvoaçam no ar roçando a cabeça de quem passe, nas conversas que fazem para vizinhos a meio de uma escalada ou lançam gritos cruzados entre janelas, nos caracóis que se saboreiam numa mesa improvisada entre duas portas" (Cordeiro 1997: 78-79).

Nessa época, havia na Bica uma "densidade do relacionamento interpessoal dos seus habitantes" (Cordeiro 1997: 95) que provinha de uma série de fatores: (a) a estabilidade residencial das famílias; (b) a mobilidade residencial realizada dentro do próprio bairro; (c) as famílias aparentadas que casavam entre si; (d) a origem comum de seus habitantes; (e) o recolhimento do bairro devido ao fato de ser pouco transitado por estranhos; (f) a semelhança de condições de vida de seus moradores decorrente dos trabalhos não especializados nos quais estavam ocupados, dos baixos níveis de instrução e da escassa remuneração recebida; $(\mathrm{g})$ o papel que as associações lúdicas tinham no fomento da identidade, da solidariedade e da mobilização coletiva. Podemos afirmar, portanto, que, em condições específicas, a forma pátio tende a promover um habitar com vizinhos. Essas condições, contudo, não estão mais presentes hoje.

Não se trata mais de famílias aparentadas. Não há mais portas abertas. $\mathrm{O}$ bairro deixou de ser fechado. Das 12 casas/apartamentos atualmente habitados do pátio, cinco são de portugueses, sendo os restantes habitados por estrangeiros (indianos, cabo-verdianos, chilenos, mexicanos, russos) que mal 
se conhecem ou se relacionam entre si. A maior parte dos habitantes é composta de homens, jovens, solteiros, que trabalham muito e que dividem as casas com outros para poderem pagar o aluguel. Quase não há crianças e as mulheres são muito poucas no pátio.

Estes homens não têm parentes no pátio e nem vizinhos com os quais possam manter relações porque sequer têm tempo para isso. Com efeito, para ficar nas portas ou nas janelas olhando a vida dos outros, para conversar com os vizinhos e visitá-los, para trocar conversas entre si, é preciso tempo. Um tempo que os desempregados ou subempregados têm, mas não os superexplorados. Um tempo que podia existir quando a jornada de trabalho culminava para todos no fim da tarde e havia espaços e hábitos de encontro nesse momento. Um tempo registrado por Nogueira de Brito no artigo "Páteos alfacinhas", de 1931: "A população dos páteos pelo cair da tarde quando o trabalho amortece, é mexida, apinha-se, estendendo-se pelos degraus e vozeando pelas frestas" (Brito 1935, apud Leite e Vilhena 1991: 71).

Foi um indiano que tingia seus cabelos numa cadeira ao sol, perto da porta de sua casa, num domingo às 13 horas, que me fez enxergar este fator. Contou-me que morava há oito anos no pátio, que antes havia morado dois anos no pátio do Forno, que gostava deste pelas plantas que tinha e que trabalhava na cozinha de uma casa de fado localizada no Chiado, bairro próximo. Tinha 38 anos, era casado e sua esposa e filha tinham chegado havia apenas quatro meses e ainda não haviam se adaptado. Disse-me não ter muito contato com os vizinhos indianos. "Mas como? Falam a mesma língua, são do mesmo país, são vários e são vizinhos, como não se frequentam?", perguntei sinceramente surpresa. "Os horários não permitem: cada um tem folgas em dias e horários diferentes e nunca estamos juntos". Carla, uma moradora portuguesa que nasceu no pátio do Broas, já tinha se referido a esse fato quando, após perguntas reiteradas sobre quando poderia encontrar seu irmão Jorge, disse-me: "moro do lado; ele é meu irmão, mas às vezes passo uma semana sem vê-lo: nossos horários são diferentes". Com efeito, percebi então que meus interlocutores constantes eram precisamente homens com um regime de trabalho diferenciado: Seu Pedro, português, morador antigo do pátio, aposentado; Ricardino, mais conhecido como Black, um cabo-verdiano desempregado; e Israel, um jovem mexicano, morador no pátio há nove meses, um freelancer.

A grande maioria dos moradores do pátio do Broas se compõe de homens relativamente jovens, em geral mal qualificados, ganhando um salário mínimo e empregados no setor de serviços ligados ao turismo (hotéis, lojas e restaurantes). Nesse setor, o sistema de trabalho supõe mais de oito horas laborais e poucas folgas, sempre em dias e horários de baixa demanda turística. Assim, cada um tem seus dias e horas de folga diferenciados e a possibilidade de se encontrar com os vizinhos ou conterrâneos do pátio é muito remota. Embora os trabalhadores contem todos com seus contratos devidamente formalizados e suas horas 
extras sejam pagas, a maioria trabalha mais de oito horas (pela necessidade de acumular turnos para pagar as contas) e só tem uma folga por semana.

A precarização das condições de trabalho tem, pois, um impacto direto nas formas de habitar. Além da "condição de instabilidade, de insegurança, de adaptabilidade e de fragmentação dos coletivos de trabalhadores e da destituição do conteúdo social do trabalho" (Druck 2013: 375) que caracteriza o trabalho precário de uma forma geral, o que a pesquisa no pátio do Broas evidencia é o efeito da precarização do trabalho no tempo do trabalhador: este se desorganiza e perde-se a rotina que antigamente permitia encontrar periodicamente os vizinhos num mesmo local e horário. Com efeito, segundo Lopes, Louçã e Ferro (2017), 14,7\% dos trabalhadores em Portugal veem o seu horário de trabalho ser alterado todas as semanas, resultando dessa dessincronização do tempo uma “individualização extrema, destroçando a pertença a comunidades" (2017: 54).

Há mais um fator que ajuda a entender, a meu ver, o habitar sem vizinhos. Trata-se da profunda mudança no próprio entorno do pátio, isto é, no bairro da Bica. "Antes era uma comunidade, agora não. As pessoas se reuniam nas tascas, no Clube Marítimo, víamos televisão, quando não havia TV como agora. Hoje não se sai e não se vê ninguém. As tascas ficaram caras", disse-me seu Pedro, que apresentei linhas acima como um de meus interlocutores mais importantes.

Com efeito, as tascas foram tradicionalmente locais de sociabilidade nos bairros. Embora a Bica não contasse com muitas há 25 anos, havia o Fado da Milu, o Domingues e a Minhota (Cordeiro 1997). Nenhum deles existe mais. As poucas tascas que subsistem têm suas atividades dirigidas para os turistas. A transformação de tascas tradicionais, pequenas, voltadas para o público interno do bairro em restaurantes, reformados e ampliados, voltados para o público externo, faz parte de processos mais complexos nos quais o bairro está inserido. Estes processos são chamados de gentrificação e envolvem basicamente a renovação de áreas deterioradas, com a chegada de novos residentes e o deslocamento das famílias de baixa renda devido ao encarecimento dos aluguéis (pela valorização imobiliária) e ao desaparecimento do pequeno comércio local (Chabrol et al. 2016; Bidou-Zachariasen 2006).

A Bica se gentrifica a passos acelerados. Apartamentos antigos se reformam e transformam em prédios de hostels ou habitações alugadas via Airbnb, mudando claramente o perfil socioeconômico dos inquilinos. ${ }^{8}$ A sensação por

8 Os hostels funcionam como albergues e caracterizam-se pelo facto de proporcionarem um tipo de alojamento mais informal e econômico. Muitos têm quartos privativos, mas todos têm quartos partilhados (mais informação em “Dica 7: Quais as diferenças entre um 'hostel' e um hotel?”, disponível em < http://saldopositivo.cgd.pt/dica-7-quais-diferencas-entre-um-hostel-e-um-hotel/ > última consulta em dezembro de 2019). Airbnb é uma plataforma online que permite arrendar temporariamente espaços em mais de 190 países. Em 2016, as freguesias da Santa Maria Maior e da Misericórdia apareciam como as duas com maior oferta de apartamentos e quartos explorados através do Airbnb em Lisboa, cada uma respectivamente com 2247 e 1992 ofertas (dados compilados por Tom Slee [continua] 
parte dos velhos moradores é a de estar perdendo o seu bairro, o seu espaço, para os estrangeiros, sejam turistas ou moradores: "A Bica tinha muita vida. Agora é só para estrangeiros. Aumentam as rendas dos velhotes e os botam para fora [...]. Isso aqui não é Lisboa, é um bairro chinês". Manolas, um antigo morador da Bica que trabalha há muito tempo no mercado, disse-me, no mesmo sentido: "Isto aqui está muito mudado. Toda casa que esvaziava virou hostels. Eu pagava 7500 escudos [faz a conta], 37 euros por mês. Morava na travessa da Portuguesa. Morava com minha mãe, que fazia limpeza. Quando morreu, minha irmã precisava de dinheiro e aceitou os 800 contos [faz as contas], 4500 euros, que o senhorio lhe ofereceu para sair".

A presença dos estrangeiros - turistas ou não - é nitidamente perceptível na Bica. São centenas a subirem e descerem as escadinhas, a fazerem fotos delas e dos lençóis secando nos varais, a passearem no funicular da rua da Bica Duarte Belo. O comércio se adequa a eles: nesta rua tem quase uma dezena de restaurantes e pequenas lanchonetes e várias lojas de lembrancinhas para turistas. A Bica, definitivamente, deixou de ser o bairro fechado e escondido que era.

As origens desta mudança da Bica devem ser buscadas em finais da década de 1990 e na década de 2000, quando começam a se sentir os efeitos da reabilitação efetuada nos bairros centrais (Alfama, Mouraria, Bairro Alto). ${ }^{9}$ No Bairro Alto, vizinho da Bica, instalou-se um importante "setor criativo" (ateliês, escolas artísticas, galerias de arte) que impulsionou a transformação da área num bairro boêmio, cosmopolita e jovem, um dito "bairro cultural". Com a reabilitação dos últimos anos, operada tanto pela pequena iniciativa individual como pelas lógicas dos promotores e das políticas públicas (Costa e Magalhães 2014), a Bica tende a seguir este modelo, com uma diferença na velocidade das transformações comparativamente ao Bairro Alto (Lopes 2014).

A partir de 2014, as freguesias centrais de Santa Maria Maior e Misericórdia viviam momentos de profundas transformações evidenciadas nos seguintes indicadores: o alojamento local representava $20 \%$ do total de alojamentos da área ${ }^{10}$

[continuação] para junho de 2016 e disponibilizados em < https://s3.amazonaws.com/tomslee-airbnb-data-2/lisbon.zip > (última consulta em dezembro de 2019).

9 A reabilitação dos bairros centrais de Lisboa se iniciou na década de 1980 em Alfama, fruto de um movimento de moradores desse bairro ao qual se integraram outros setores da sociedade civil (professores, arquitetos, etc.) que interpelaram os poderes públicos e conseguiram a criação pela Câmara, em 1985, de um gabinete técnico local com vistas à reabilitação. A manutenção da população moradora era uma exigência fundamental para a futura reabilitação. Segundo a opinião de António Firmino da Costa (1999), em finais da década de 1990, em Alfama, essa reabilitação não tinha desembocado numa gentrificação do bairro, pois não havia uma substituição generalizada de moradores anteriores por outros com diferente perfil social. Havia, sim, uma recomposição exógena, porém sem características esmagadoras. Continuava sendo um bairro popular, embora o sociólogo admitisse uma "grande margem de indeterminação quanto ao futuro" (Costa 1999: 451).

10 Informação do secretário de Estado adjunto e do Ambiente, José Mendes, na palestra de abertura da conferência internacional "Lisboa, Que Futuro?", realizada nos dias 17 e 18 de abril [continua] 
e a concessão de alvarás de obras nestas freguesias cresceu 540\% (Pereira 2017). Este enorme crescimento de investimentos imobiliários, com majoritária participação de capital estrangeiro, principalmente chinês e francês, foram e são possíveis devido à grande desertificação do centro, à alta porcentagem de edifícios devolutos (P. Costa 2017) e, segundo Carla Madeira, presidente da Junta da Freguesia da Misericórdia, também à nova Lei do Arrendamento (em vigor desde novembro de 2012) e ao Regime Jurídico da Exploração dos Estabelecimentos do Alojamento Local, que levaram, respectivamente, ao aumento "de forma exponencial" dos preços de aluguel das habitações e a uma maior facilidade em utilizar "residências para uso turístico" (Banha 2016). A recente nomeação da rua da Bica Duarte Belo como uma das sete ruas mais bonitas do mundo certamente exacerbará este processo. ${ }^{11}$

Um impulso especial para a transformação recente da parte baixa da Bica, ribeirinha, decorreu da reabilitação do velho mercado da Ribeira, empreendida pelo grupo empresarial Time Out. ${ }^{12} \mathrm{O}$ sucesso do Time Out Market transformou os arredores do mercado, incluindo o largo de São Paulo, hoje com mesinhas ao ar livre, servidas por um quiosque, que atende os turistas que descem ou sobem para o point turístico do largo do Chiado ou para a sofisticada rua Garrett. Transformou também as ruas próximas, onde vieram a se instalar uma dezena de restaurantes caros, com comida requintada e internacional. Transformou, finalmente, a rua de São Paulo (em cujas margens se localiza o prédio onde, na parte traseira, ergueu-se o pátio do Broas), que hoje vê seu metro quadrado se tornar o mais caro de Lisboa, seguido de perto pela Baixa e Bairro Alto (Pereira 2017). Assim, nessa rua, há atualmente seis prédios sendo reformados, onde serão oferecidos modernos apartamentos. O comércio local - que hoje se compõe de restaurantes simples (cujos pratos custam em média oito euros), padarias, mercadinhos, loja de material elétrico, lojas de miudezas para turistas, frutarias, bistrôs, minimercado, ourivesaria, supermercado pequeno, loja de eletrodomésticos e sapataria - certamente irá mudar, acompanhando o público que virá e suas exigências.

de 2017, no ISCTE-IUL, em Lisboa. A categoria alojamento local (AL) diz respeito aos locais que prestam serviço de alojamento temporário a turistas seguindo um regime jurídico específico (Decreto-Lei n. ${ }^{\circ}$ 63/2015, de 23 de abril). As modalidades de AL podem ser casas unifamiliares, apartamentos em prédios ou quartos (ver mais informação no site da Associação da Hotelaria, Restauração e Similares de Portugal, < https://ahresp.com/ > última consulta em dezembro de 2019).

11 Ver "As ruas mais bonitas: da Bica em Lisboa à 5. avenida em Nova Iorque", Jornal de Notícias, 25/02/2017, disponível em <http:/www.jn.pt/mundo/galerias/interior/as-ruas-mais-bonitas-do-mun do-da-bica-em-lisboa-a-5a-avenida-em-nova-iorque-5691535.html > (última consulta em dezembro de 2019).

12 O mercado da Ribeira ocupa um quarteirão (um terreno de $7000 \mathrm{~m}^{2}$ ) contíguo à praça D. Luís, à rua da Ribeira Nova, ao Cais do Sodré e à avenida 24 de Julho, onde tem sua porta principal. Nele funciona atualmente o Time Out Market Lisboa (mais informação em < https://www.timeoutmarket. com/lisboa/ > (última consulta em dezembro de 2019). 


\section{CONSIDERAÇÕES FINAIS}

Os dados empíricos produzidos na "avenida" Camponesa e no pátio do Broas nos permitem afirmar que os lugares não contêm formas de habitar intrínsecas. O espaço construído não engendra um conteúdo específico. Concordamos, assim, com a geógrafa Doreen Massey quando afirma que "a forma espacial abstrata em si não pode garantir nada sobre o conteúdo social, político ou ético das relações que constroem aquela forma" (Massey 2012: 151). As práticas que conformam os modos de habitar devem ser explicadas por fatores outros que não a forma física ou o espaço construído.

Sinteticamente, podemos dizer que as práticas do habitar com vizinhos derivam de quatro fatores: a disposição do tempo livre decorrente do regime de trabalho no qual estão inseridos seus habitantes; a propriedade dos imóveis; a concepção de casa associada com o hábito de viver perto dos parentes; o relativo fechamento dos ambientes.

O tempo livre é um fator essencial para a produção de relações de envolvimento e enraizamento dos seres que compõem um espaço e entre eles. Este tempo está diretamente relacionado com o tipo ou fase de capitalismo que se desenvolve em cada sociedade. Em Salvador, o "capitalismo periférico" deixa brechas para a sobrevivência artesanal e cria um grande exército industrial de reserva, de desempregados, o que explica o grande número de "zonas opacas" e "homens lentos" (Santos 1996) que, embora sem dinheiro, dispõem de tempo para deambular, conversar, olhar, visitar parentes, ficar nas portas e janelas, acompanhar as novidades do beco, etc. Em Lisboa, o capitalismo neoliberal impõe um tempo frenético aos trabalhadores superexplorados que, empregados em vários turnos, conseguem pagar suas contas, mas não têm tempo para desenvolver práticas de plasticidade, negociação, abertura ou circulação com ou entre os vizinhos.

A propriedade dos imóveis parece ser um fator igualmente decisivo para a promoção das práticas que caracterizam o habitar com vizinhos. Como vimos, no pátio do Broas, todos os moradores são inquilinos; na "avenida" Camponesa, 88\% dos moradores são proprietários de suas casas ou se sentem tal. A propriedade neste beco se explica pela grande quantidade de casas construídas em terrenos ocupados, disponíveis na proximidade do beco desde a década de 1970. A propriedade é um fator importante por duas razões: primeiro, porque possibilita as práticas do "avançar" das casas, que promovem e supõem a negociação entre vizinhos, ou seja, a sua relação; segundo, porque permitem a construção em altura, o que, por sua vez, possibilita a manutenção da tradição de os filhos morarem perto de suas mães, perpetuando as práticas que emanam das casas aparentadas.

A concepção da casa como um espaço coletivo, sempre inacabado, por definição aberto aos parentes (sanguíneos ou de consideração), parece ser um fator, 
outrossim, decisivo. A abertura das casas na "avenida" Camponesa promove as práticas de ficar nas portas, janelas e escadas, sem isso ser visto negativamente. A circulação de conversas, sons e cheiros suscita um ambiente relacional denso que se vê potencializado pela circulação dos vizinhos entre casas aparentadas.

Por fim, o relativo fechamento do ambiente apresenta-se como outro fator definidor do habitar com vizinhos. A "avenida" Camponesa é um ambiente relativamente fechado: só entram no beco moradores ou conhecidos, todos são familiares uns dos outros, de longa data. Já no pátio do Broas, a gentrificação em curso no bairro promove uma circulação maior de inquilinos e os guias de turismo estão inclusive incorporando a entrada no pátio para exibir a bica d'água que dá nome ao bairro. O pátio está abrindo-se para a cidade e o mundo, de modo que as relações nele se modificam.

Neste ponto, é preciso frisar alguns indícios de transformações nas duas formas de habitar aqui descritas que nos levam a concluir que essas formas de habitar estão em constante recomposição. O habitar em vizinhança dos becos/avenidas da Baixa dos Sapateiros é um conjunto de práticas que, de fato, substituíram outras. Os depoimentos de muitos de seus moradores que antes habitavam a área conhecida como Pelourinho - que passou por um processo de "revitalização" nos anos 1990 - lamentam o desaparecimento da "comunidade" na qual moravam, cuja característica principal era a absoluta igualdade entre todos os moradores. Quando passaram a morar na "avenida" Camponesa, sentiram muitas diferenças, separando os moradores neste novo espaço: entre os que têm mais dinheiro e os que têm menos, entre os mais antigos e os mais recentes, os inquilinos e os proprietários, os "invasores" e os "compradores", os que têm o poder da arma e os que não o têm. Esta divisão fratura o laço social porque implica não apenas uma diferença entre moradores, mas uma desigualdade entre eles. Sem igualdade, não se fala mais em "comunidade", fala-se em "vizinhança". Mas o habitar com vizinhos também está se transformando. A "lei do silêncio" imposta pelo tráfico de drogas do beco restringe as interações. As pessoas passaram a ter medo de falar, medo de ouvir, medo de ver e serem vistas. As práticas de ficar nas portas, sentar-se nos degraus das escadas, permanecer vendo e sendo vistas nas janelas corre um sério risco de não poder se reproduzir.

Por outro lado, no pátio do Broas, 25 anos atrás, habitava-se com vizinhos (Cordeiro 1997; Leite e Vilhena 1991); hoje, habita-se sem vizinhos. Este habitar baseado na distância pode muito bem se transformar brevemente em outra forma de habitar. Os moradores têm consciência de que a morte da proprietária é uma questão de tempo e que os herdeiros quererão vender a propriedade. Alguns moradores esperam lucrar com isso e mantêm-se no pátio especificamente com esse fim. Um deles foi bastante sincero a esse respeito: "Tenho uma casa, longe daqui. Estou aqui para me manter como morador e receber uma indenização quando tudo for vendido". Nesse sentido, esta pode 
ter sido uma etnografia de um campo com uma morte anunciada pela gentrificação que já acontece nos arredores do pátio. E outra forma de habitar desenvolver-se-á nele. Estas transformações ratificam que os espaços não contêm formas de habitar intrínsecas a eles nem as formas de habitar que neles se desenvolvem são definitivas no lugar.

\section{BIBLIOGRAFIA}

AGIER, Michel, 201 1, Antropologia da Cidade: Lugares, Situações, Movimentos. São Paulo, Terceiro Nome.

AMADO, Jorge, 1983, Bahia de Todos os Santos: Guia de Ruas e Mistérios. São Paulo, Record (35. ${ }^{\mathrm{a}}$ edição).

BACHELARD, Gaston, 1998, A Poética do Espaço. São Paulo, Martins Fontes.

BANHA, Inês, 2016, "Lisboetas deixam casas em bairros históricos para arrendar a turistas", Diário de Notícias, 31 de janeiro, disponível em < http://www.dn.pt/sociedade/interior/ lisboetas-deixam-casas-em-bairros-historicos-para-arrendar-a-turistas-5007426.html > (última consulta em dezembro de 2019).

BERNARD, Yvonne, 1995, "Ménages et modes de vie", em F. Asher (org.) Le logement en questions: L'habitat dans les années quatre-vingt-dix, continuités et ruptures. Paris, Edition de l'Aube, 13-39.

Bidou-ZaChariasen, Catherine (org.), 2006, De Volta à Cidade: Dos Processos de Gentrificação às Políticas de "Revitalização" dos Centros Urbanos. São Paulo, Annablume.

BRITO, J.J. Gomes de, 1935, Ruas de Lisboa. Lisboa, Livraria Sá da Costa, 3 vols.

CARDOSO, Luiz Antonio Fernandes, 1991, Entre Vilas e Avenidas: Habitação Proletária em Salvador na Primeira República. Salvador, Universidade Federal da Bahia, dissertação de mestrado. CHABROL, Marie, et al., 2016, Gentrifications. Paris, Editions Amsterdam.

CLAVEL, Maité, 2015, "Elementos para uma nova reflexão sobre o habitar", Revista Antropolítica, 38: 147-167.

CORDEIRO, Graça Índias, 1997, Um Lugar na Cidade: Quotidiano, Memória e Representação no Bairro da Bica. Lisboa, Publicações Dom Quixote.

CORDEIRO, Graça Índias, 2014, "Pátios”, em C. Topalov et al. (org.), A Aventura das Palavras da Cidade, através dos Tempos, das Linguas e das Sociedades. São Paulo, Romano Guerra, 469-479.

COSTA, Ana de Lourdes Ribeiro da, 1989, Ekabó! Trabalho Escravo, Condições de Moradia e Reordenamento Urbano em Salvador no Século XIX. Salvador, Universidade Federal da Bahia, dissertação de mestrado.

COSTA, António Firmino da, 1999, Sociedade de Bairro. Oeiras, Celta Editora.

COSTA, Pedro, 2017, "A minha gentrificação é melhor do que a tua: o(s) direito(s) à cidade numa Lisboa em massificação", apresentado na conferência internacional "Lisboa, Que Futuro?", Lisboa, ISCTE-IUL, 17 e 18 de abril. 
COSTA, Pedro, e Andreia MAGAlHÃES, 2014, "Novos tempos, nova vida, novo centro? Dinâmicas e desafios para uma vida nova do centro histórico de Lisboa”, Rossio: Estudos de Lisboa, 4: 16-27.

DaMATTA, Roberto, 1985, A Casa e a Rua: Espaço, Cidadania, Mulher e Morte no Brasil. São Paulo, Brasiliense.

DAVID, Onildo Reis, 1996, O Inimigo Invisível: A Epidemia na Bahia no Século XIX. Salvador, EdUFBA.

DRUCK, Graça, 2013, "Precarização social do trabalho", em A.B.L. Ivo (org.). Dicionário Temático Desenvolvimento e Questão Social: 81 Problemáticas Contemporâneas. São Paulo, Annablume; Brasília, CNPq; Salvador, FAPESB, 373-380.

FREYRE, Gilberto, 2004, Sobrados e Mucambos: Decadência do Patriarcado Rural e Desenvolvimento do Urbano. São Paulo, Global Editora.

GORDILHO, Ângela, 2008, Limites do Habitar: Segregação e Exclusão na Configuração Urbana Contemporânea de Salvador e Perspectivas no Final do Século XX. Salvador, EdUFBA.

HALl, Edward, 1973, La Dimensión Oculta: Enfoque Antropológico del Uso del Espacio. Madrid, Instituto de Estudios de Administración Local.

HAUMONT, Bernard, 2005, "Préface", em B. Haumont e A. Morel, La societé des voisins: partager un habitat collectif. Paris, Edition de la Maison des Sciences de l'Homme, xv-xxxiii.

HEIDEGGER, Martin, s.d. [1954], "Construir, habitar, pensar”, tradução de Marcia Sá Cavalcante Schuback disponível em < http://www.fau.usp.br/wp-content/uploads/2016/12/ heidegger_construir_habitar_pensar.pdf > (última consulta em dezembro de 2019).

HITA, Maria Gabriela, 2014, A Casa das Mulheres Noutro Terreiro: Famílias Matriarcais em Salvador-Bahia. Salvador, EdUFBA.

INGOLD, Tim, 2002, The Perception of the Ambience: Essays on Livelihood, Dwelling and Skill. Londres, Routledge.

KOVARICK, Lúcio, 2009, Viver em Risco: Sobre a Vulnerabilidade Socioeconômica e Civil. São Paulo, Editora 34.

LEFEBVRE, Henri, 1970, Du Rural à l'Urbain. Paris, Anthropos.

LEFEBVRE, Henri, 1991 [1969], O Direito à Cidade. São Paulo, Editora Moraes.

LEFEBVRE, Henri, 2001 [1966], "Préface", em H. Raymond et al., L'habitat pavillonaire. Paris, L'Harmattan, 7-23.

LEITE, Cristina, e João Francisco VILHENA, 1991, Pátios de Lisboa: Cidades entre Muros. Lisboa, Gradiva.

LIMA, Adriana, 2016, Do Direito Autoconstruído ao Direito à Cidade: Porosidades, Conflitos e Insurgências em Saramandaia. Salvador, Universidade Federal da Bahia, tese de doutorado.

LOPES, Ricardo Venâncio, 2014, "Do Bairro Alto ao Cais do Sodré: criatividade, informalidade e recomposição física, social, funcional e económica”, Rossio: Estudos de Lisboa, 4: 80-93.

LOPES, João Teixeira, Francisco LOUÇÃ, e Lígia FERro, 2017, As Classes Populares: A Produção e a Reprodução da Desigualdade em Portugal. Lisboa, Bertrand Editora.

MARCELIN, Louis Herns, 1999, "A linguagem da casa entre os negros no Recôncavo baiano", Mana, 5 (2): 31-60, disponível em < http://www.scielo.br/scielo.php?script=sci_arttext\& pid=S0104-93131999000200002 > (última consulta em dezembro de 2019).

MARINS, Paulo César Garcez, 2006, "Habitação e vizinhança: limites da privacidade no surgimento das metrópoles brasileiras", em N. Sevcenko (org.), História da Vida Privada no Brasil, vol. 3: República: Da Belle Époque à Era do Rádio. São Paulo, Companhia das Letras, 131-214. 
MASSEY, Doreen, 2012, Pelo Espaço: Uma Nova Política da Espacialidade. Rio de Janeiro, Bertrand Brasil.

MAYOL, Pierre, 2009, "Morar", em M. Certeau, L. Giard e P. Mayol, A Invenção do Cotidiano 2: Morar, Cozinhar. Petrópolis, Vozes, 37-185.

McCAllum, Cecilia, e Vania BUSTAMANTE, 2012, "Parentesco, gênero e individuação no cotidiano da casa em um bairro popular de Salvador da Bahia”, Etnográfica, 16 (2): 221 -246, disponível em < https://etnografica.revues.org/1476 > (última consulta em dezembro de 2019).

MONTOYA URIARTE, Urpi, 2012, "O que é fazer etnografia para os antropólogos", Ponto Urbe, 11, disponível em < https://journals.openedition.org/pontourbe/300> (última consulta em dezembro de 2019).

MOPCI - Ministério das Obras Públicas, Commercio e Indústria, 1905, Inquérito aos Páteos de Lisboa, 2. ${ }^{a}$ Parte. Lisboa, Imprensa Nacional.

PEREIRA, Nuno Teotónio, 1994, "Pátios e vilas de Lisboa, 1870-1930: a promoção privada do alojamento operário", Análise Social, XXIX (127): 509-524.

PEREIRA, Sandra Marques, 2016, Casa e Mudança Social: Uma Leitura das Transformações da Sociedade Portuguesa a Partir da Casa. Lisboa, Caleidoscópio.

PEREIRA, Sandra Marques, 2017, "Lisboom: a cidade renascida em contexto de globalização", apresentado na conferência internacional "Lisboa, Que Futuro?", Lisboa, ISCTE-IUL, 17 e 18 de abril.

PINA-CABRAL, João de, e Vanda Aparecida da SILVA, 2013, Gente Livre: Consideração e Pessoa no Baixo Sul da Bahia. São Paulo, Terceiro Nome.

RAYMOND, Henri, et al., 2001 [1966], L'habitat pavillonaire. Paris, L'Harmattan.

RIBEIRO, Luiz Cesar de Queiroz, 1997, Dos Cortiços aos Condomínios Fechados: As Formas de Produção da Moradia na Cidade do Rio de Janeiro. Rio de Janeiro, Civilização Brasileira, IPPUR, UFRJ, FASE.

ROJAS, Sergio, 2013, "El desenlace de la 'cotidianidad obrada'”, em J. S. Opazo, La Derrota de lo Cotidiano: Elementos para Una Ontología Política del Diseño Contemporáneo. Santiago do Chile, CEAUP, Universidad Central.

SANTOS, Milton, 1996, A Natureza do Espaço: Técnica e Tempo, Razão e Emoção. São Paulo, Hucitec.

SIMMEL, Georg, 1967, "A metrópole e a vida mental”, em O. G. Velho (org.), O Fenômeno Urbano. Rio de Janeiro, Zahar, 13-28.

SIMMEL, Georg, 1996, "A ponte e a porta", Revista Política e Trabalho, 12: 1 1-15, disponível em < https://periodicos.ufpb.br/ojs/index.php/politicaetrabalho/article/view/6379/19750> (última consulta em dezembro de 2019).

TeIXeIrA, Manuel C., 1996, Habitação Popular na Cidade Oitocentista: As Ilhas do Porto. Lisboa, Fundação Calouste Gulbenkian; Junta Nacional de Investigação Científica e Tecnológica.

Receção da versão original / Original version

Receção da versão revista / Revised version

Aceitação / Accepted

Pré-publicação online / Pre-published online
$2018 / 03 / 09$

$2018 / 08 / 03$

$2018 / 12 / 28$

$2019 / 12 / 31$ 